\title{
Simple memes and complex cultural dynamics*
}

\author{
David Batten ${ }^{0}$ and Roger Bradbury \\ ${ }^{0}$ CSIRO, Melbourne, Australia \\ \#Australian National University, Canberra, Australia
}

\begin{abstract}
Policies and regions are built on many things, such as ideas, actions, behaviours, habits, skills, inventions, songs and stories, to name a few. This paper views all of these as selfish Darwinian entities memes - that, like genes, interact and replicate in complex ways with humans to shape our culture. Perniciously, simple memes can exploit our limited capacity to deal collectively with complex problems. Whether good or bad, a single, omnipotent meme can dominate a local region of meme-space.
\end{abstract}

\section{Introduction}

Public policy sets the framework for the conduct of human affairs. Whether grandly enshrined in law and treaty, or more humbly promulgated as municipal regulation, the intent is always the same - the civilising of interactions between and among individuals, communities, regions and nations. Irrespective of whether policy concerns basic human needs like food, shelter and sex, or the arcana of intellectual property rights arising from new ideas, actions and artefacts, it always deals with the nature of Homo sapiens — that peculiar animal imbued with culture.

Can we develop a science of public policy? In order to understand what makes good policy, and what makes some policies fail while others succeed, we need to embed it in a theory of human culture that is at least consistent with evolution. Dennett (1) calls this 'minimal Darwinism'. Because culture is the playground of other evolving entities

\footnotetext{
* The arguments contained in this paper originated at a workshop on "Memes as Complex Systems" held in Canberra from 13-17 August 2004 and funded by CSIRO's Centre for Complex Systems Science [see (2)].
} 
In: C Karlsson, Å E Andersson, P C Cheshire and R R Stough (eds) (2009) New directions in regional economic development. Heidelberg, Springer. pp 97-105

besides humans, any proper understanding of policy must be built along Darwinian lines. We need, in fact, to understand how policy depends on the complex interplay between humans, genes and memes. Our contention in this paper, as in an earlier one (2), is that a science of co-evolving ideas, habits, actions and artefacts - in fact, all the elements of human culture - could be built on Dawkins notion of the meme (3) using the analytical tools of complex systems $(4,5,6)$.

Genes appear to be selfish (3). That is, the interests of the genes and the interests of the organisms in which they live may not always coincide. Although genes are not conscious, purposeful agents, blind natural selection makes them behave as if purposeful. This Darwinian idea of purpose or self-interest is only a metaphor, of course, ensuring that genes will grow and spread blindly through the world. Genes that encourage parents to take (sometimes fatal) risks to protect their young, for example, serve the interest of the genes, not the organism, by increasing the chance that copies of the genes survive (in the offspring) even as they decrease the chance that the parent survives. Genes treat organisms as vehicles to protect them from the vagaries of the environment and increase their chances of survival.

Dawkins extended this notion of vehicle to the things that organisms create in their environment (7), be they beaver dams or human culture. He coined the term memes to describe how human ideas, objects and artefacts can be thought of as agents evolving separately from their human hosts, owing their existence as entities to contingent facts about brains and their interactions. Their dynamics are governed by the principles of Universal Darwinism (8). This is the idea that if the conditions for Darwinian evolution are met then it will, indeed, must occur. The conditions are that the entities should exhibit heredity or replication (be copied from one generation to the next), variation (an abundance of different elements, because copying is not perfect), and natural selection (some of the exhibited variation is associated with conditions of existence). Genes, based on DNA and RNA, fulfil these conditions, and so life has evolved.

But other entities in the world - such as prions (9), the computer programs of artificial life (10), and memes (11) — also fulfil the conditions of Universal Darwinism. Thus they must evolve and they must act as if they are selfish. They will differ from each 
Roughly spliced draft only

In: C Karlsson, Å E Andersson, P C Cheshire and R R Stough (eds) (2009) New directions in regional economic development. Heidelberg, Springer. pp 97-105

other and from genes in how they evolve, but that they evolve and have interests that appear to be selfish can hardly be in doubt.

The crucial idea about memes - what makes them uniquely Darwinian - is that if a meme can get itself copied it will. The new Oxford English Dictionary defines meme (n. Biol.): 'An element of a culture that may be considered to be passed on by nongenetic means, esp. imitation.' When we imitate someone else, something gets passed on. Copying and imitation come naturally to human beings. In fact, what makes humans different from other animals is our ability to imitate (11). That which gets passed on can be passed on again, and again, and thus takes on a life of its own. And that is what makes the meme a replicator and gives it replicative power. Education and imitation are ways of transmitting ideas, habits and behaviours from one vehicle to another. It has been said that a chicken is just an egg's way of making another egg. As Dennett suggests, perhaps a scholar is just a library's way of making another library (8).

A meme's existence depends on physical embodiment in one medium or another. Like genes, memes are potentially immortal. But, also like genes, they depend for their existence of a continuous chain of physical vehicles. Books, buildings and music are relatively permanent, as are inscriptions on monuments. But unless all of these are under the protection of human conservators, they tend to dissolve over time. Manfred Eigen makes a similar point:

"Consider, for instance, one of Mozart's compositions, one that is retained stably in our concert repertoire. The reason for its retention is not that the notes of this work are printed in a particular durable ink. The persistence with which a Mozart symphony reappears in our concert programmes is solely a consequence of its high selection value. In order for this to retain its effect, the work must be played again and again, the public must take note of it, and it must be continually re-evaluated in competition with other compositions" (12).

\section{Cui Bono?}

Lawyers often ask (in Latin), Cui Bono? Who benefits from this matter? - A question that strikes at the heart of important policy issues. In the case of evolutionary theory, by and 
Roughly spliced draft only

In: C Karlsson, Å E Andersson, P C Cheshire and R R Stough (eds) (2009) New directions in regional economic development. Heidelberg, Springer. pp 97-105

large the fate of a body and the fate of its genes are closely linked. But when push comes to shove, the evidence suggests that what's good for the genes determine what the future will hold. A "gene's-eye-point-of-view" explains things in terms of the complex interactions between long-range, large-scale ecological facts, long-term historical facts, and local, molecular-level facts (7).

Many people feel threatened by this gene's-eye-point-of-view. They want to be in charge of their own destinies - or at least feel that they are. After all, none of us want our interests playing second fiddle to something else! But soon the threat may come more from non-genetic sources. Memes are outpacing biological change. Cultural evolution operates many orders of magnitude faster than genetic evolution, so it may not be long before what's good for the memes may determine what the future will hold, partly at the expense of our genes. What better example is there of this phenomenon than the Internet - a meme itself and a lightning-fast transmitter of memes.

If memes, as well as genes, build humans and their culture to further their own interests, then even bigger questions loom. Where is human purpose or free will in this description (13-15)? Modern genetics has undermined the belief that humans are born with the freedom to shape their individual destinies. Scientists recognize that genes shape our minds as well as our bodies. Evolutionary psychologists place personal qualities like altruism and aggression - squarely in the Darwinian camp of random mutation and natural selection (15). If memes have a hand in shaping our minds as well, then who is really in charge - ourselves or our memes? Can humans possibly survive as the ruling vehicles in the face of such a complex mix of memetic influences operating at vastly different speeds?

There are no simple answers to these questions. You may be appalled by the idea of your brain being

" a sort of dungheap in which the larvae of other people's ideas renew themselves, before sending out copies of themselves in an informational diaspora" (8).

It does seem to rob your mind of its importance as both author and critic. Most of us would like to think of ourselves as godlike creators of ideas, manipulating and controlling 
Roughly spliced draft only

In: C Karlsson, Å E Andersson, P C Cheshire and R R Stough (eds) (2009) New directions in regional economic development. Heidelberg, Springer. pp 97-105

them as our whim dictates. But, even with the most masterful and creative minds, this is seldom, if ever, the reality. As Mozart observed of his own "brainchildren":

When I feel well and in a good humour, or when I am taking a drive or walking after a good meal, or in the night when I cannot sleep, thoughts crowd into my mind as easily as you would wish. Whence and how do they come? I do not know and I have nothing to do with it. Those which please me I keep in my head and hum them; at least others have told me that I do so" (8).

\section{Genes, Memes and Replicators}

One challenge for understanding genes and memes is how to transfer some of the deep knowledge and understanding of genetics to the domain of memes without imposing the particulars of genetics that are the result of the way living things are built. In fact, the field of memetics has probably been held back by attempts to map memetic to genetic phenomena too precisely (13). Perhaps a more useful framework for memetics may be found in complex systems science. It provides a rich array of theory and practice for gaining insight into the emergent properties of systems whose dynamics range from adaptive to evolutionary in the strict Darwinian sense (\%).

Embryonic and cultural development can be looked upon partly as the evolution of cooperation (16). Axelrod's computer tournaments among different strategies in ceaseless games of the Prisoner's Dilemma serve as useful metaphors for the way we can think of animals, plants, and even genes (3). It is natural to ask whether his optimistic conclusions - about the emergent success of nice, forgiving, non-envious strategies like Tit for Tat - also apply in the world of nature. Dawkins' answer is yes, of course. So long as the shadow of the future is long, and games are of the non-zero sum variety, embryonic development can be viewed as a cooperative venture-jointly run by thousands of genes together. In natural selection, genes are selected for their capacity to flourish in the environment in which they find themselves. We usually think of this environment as the outside world, that world of predators and climate. But, from the gene's-eye-point-of-view, possibly the most important part of its environment is all the other genes that it encounters. 
Roughly spliced draft only

In: C Karlsson, Å E Andersson, P C Cheshire and R R Stough (eds) (2009) New directions in regional economic development. Heidelberg, Springer. pp 97-105

A gene encounters other genes mostly in the cells of the successive individual bodies in which it finds itself. Each gene is selected for its capacity to cooperate successfully with the population of other genes that it is likely to meet in other bodies. Could the same be true of memes? From the meme's-eye-point-of-view, possibly the most important part of its environment is all the other memes that it encounters. Memes encounter one another mostly in the brains of the successive individual bodies in which they find themselves. Could it be that each meme is selected for its capacity to interact successfully with the population of other memes that it is likely to meet? Then, doing well in such environments would correspond to collaborating with these other memes.

Another interesting parallel between genes and memes is their informational nature. As an evolutionary unit, a long-lived gene is not any particular physical structure but the textual, archival information that is copied on down the generations. This textual replicator is widely distributed in space among individuals, and widely distributed in time over many generations. The population of genes is not just the temporary collection that happens to come together in the cells of any particular body, but the set of all genes in the population of inter-breeding individuals - the gene-pool. Just as genes propagate themselves in the gene-pool by passing archival information on from body to body via sperm or eggs, memes propagate themselves in the meme-pool by passing information on from brain to brain via an imitative process.

The above gives rise to a technical question: how do memes and genes interact to create the vehicles that allow them to replicate? Perhaps it is through the emergence of autonomous structures by modularisation and hierarchical organization. Perhaps selforganization may be a key architect. These are well-described complexity phenomena in other problem domains. We shall steer around this Scylla and Charybdis for the moment, charting a more pragmatic course by examining some particulars of how public policy as a purposeful domain of ideas may be driven by memes.

\subsection{Vignette Number One}

Consider, first, international development aid. It is an area where public policy has failed spectacularly, and in a way that continues to confound conventional explanations. 
Roughly spliced draft only

In: C Karlsson, Å E Andersson, P C Cheshire and R R Stough (eds) (2009) New directions in regional economic development. Heidelberg, Springer. pp 97-105

Despite transfers of vast amounts of money over many decades from the rich world to the poor, poor countries are getting poorer while the rich get richer. Memetics allows us to propose a testable scientific explanation for this continuing policy failure.

Our model suggests that aid is an expression of a biologically-based altruistic drive modulated in Western culture by two sets of memes entrenched at least since the Enlightenment: ideas of universal human values and ideas of progress and technological control. Together these encourage simplistic intervention in the complex system that is some other (non-Western) culture - where such memes are not strongly established. But these memes never need become established in poor countries for them to continue to prosper in rich ones. All that is needed is that memes emanating from the poor countries reinforce those in the rich.

Simple memes carried in pictures of starving children - regardless of their truthvalue - created in poor countries replicate well in rich countries. Simplicity serves the interests of this new cluster of memes, and encourages continued simplistic intervention, regardless of the actual effects - good or bad — of the aid. We may predict confidently that development aid will continue to be a naïve and failing intervention in a complex system, and that it will continue to fail for so long as the interests of these simplistic clusters — meme complexes — are satisfied.

\subsection{Vignette Number Two}

The War on Terror is another case where public policy is in trouble. Historically tested policy settings failed to either anticipate or cope with this new international security emergency. The intelligence and security services of key members of 'the coalition of the willing' (USA, UK and Australia) have each been reviewed to discover why the West was caught napping. The usual bureaucratic reasons - lack of cooperation and coordination — and the usual policy nostrums - creation of new organisational structures - have been aired. But a memetic perspective offers a different insight, as well as new directions.

We say that fundamentalist Islamic terrorism is an emergent property of the complex adaptive system that is our strongly-interacting cultural world. It was created 
In: C Karlsson, Å E Andersson, P C Cheshire and R R Stough (eds) (2009) New directions in regional economic development. Heidelberg, Springer. pp 97-105

from the historical interplay of humans and memes. It was never entirely predictable that it would come into being, for the emergent properties of complex adaptive systems are not generally predictable, even in principle (4). And in that sense, the intelligence services did not fail, in failing to predict it. But now that it exists, it can be understood, and that understanding can guide policy. And the key lies in understanding the balance of interests among the memes in play in the brains of terrorists.

Clearly, terrorism memes have found a very successful strategy for their replication and spread, especially by associating with powerful and long-lived religious memes and by using new channels such as television and the internet to spread from brain to brain. We predict that no policy based only on stopping acts of terrorism or locking up or killing terrorists can be successful, since the terrorism memes are not affected by this. However a policy to change the selective pressure on terrorism memes - perhaps on their linkage with religious memes - could drastically reduce the spread of these memes. The global outbreak of terrorism could collapse or, more likely, evolve to something like local gangsterism (as in the Irish situation) that can be handled by normal policing. And this could occur despite the absence of any other social or political reforms, such as democratisation or market reforms.

\subsection{Vignette Number Three}

Our third example concerns recreational drug use. Many such drugs are intensely pleasurable to human beings. Some of these drugs are harmful to health. But drug policy often creates social and economic problems that are, arguably, out of all proportion to that harm. These include the huge black market, the cost of policing, the size of prison populations, the criminalisation of children, and the financing of terrorism and organised crime. Existing models of the drug user — sick person, social victim, and sinner — fail to adequately describe the situation or produce better policy.

We suggest that drug policy is stymied because simple memes — such as 'drugs are bad' - are often more successful than complex ones, and successful memes attract other memes - ideas of criminality, morality, sociality and so on - to form even more powerful complexes. The interests of this meme complex — or memeplex (9) — are 
In: C Karlsson, Å E Andersson, P C Cheshire and R R Stough (eds) (2009) New directions in regional economic development. Heidelberg, Springer. pp 97-105

served by the actions of all human players in our society - licit and illicit, users and nonusers, victims and victors - and it has become so powerful that it excludes all other competing memes. But complexity theory allows us to imagine a richer universe of policy possibilities built on biological predispositions and pharmacological effects, and to see the current policy as a deep basin of attraction in a policy landscape. We know, for example, that Amazonian Indians using the drug ayahuasca have a core meme: drug use is dangerous but can lead to spiritual experiences. This allows the memes associated with ritual, social control, art and creativity to form memeplexes not found in other societies. Exploration of the policy landscape in the vicinity of such memes could provide the opportunity for the evolution of memes that are both successful as memes and beneficial to their human hosts.

\subsection{Vignette Number Four}

Our final example focuses on American economic policy, where fiscal irresponsibility seems to be politically seductive. Once again, the world's largest debtor is touting huge tax cuts as stimulants to economic growth and massive increases to defense spending (17). In the early $1980 \mathrm{~s}$, the Reagan administration did the same. Its reasoning was simple: middle-class Americans are overregulated and overtaxed, groaning under the weight of Big Government. Reagan illustrated his point with striking images such as welfare queens driving Cadillacs and huge rooms full of bureaucrats each taking care of a single Indian (18). Yet all these images were fantasies and Reagan's stance highly questionable. Middle-class Americans pay lower taxes than residents of other advanced nations and most of those taxes go to pay for their own social programs.

Why did Reagan build his political stance on a compelling mythology so far from reality? Was he simply too frightened to do the necessary? Raising taxes and cutting spending are extremely painful. A political leader needs to be convinced that the pain is worth it. A memetic perspective, however, offers a different explanation. First, we must ask where ideas about economics come from? Most come from economists. But not all economists are alike. Krugman (19) claims that the genus includes two radically different species: professors and policy entrepreneurs. A professor writes mostly for 
In: C Karlsson, Å E Andersson, P C Cheshire and R R Stough (eds) (2009) New directions in regional economic development. Heidelberg, Springer. pp 97-105

other professors. Lurking behind his words - no matter how simple - are concepts too complicated for a broad audience to understand. On the other hand, a policy entrepreneur writes and speaks in simple terms, largely for that broader audience.

In the late 1970s, a powerful group of policy entrepreneurs - the "supply-siders" came upon the political scene. Mostly journalists and political staffers, they shunned demand-side policies and proclaimed that sharp tax cuts will produce a huge surge in economic growth. Reagan loved this meme and based his campaign on these supply-side cranks. Supply-side memes flourished and spread. "Voodoo economics" ruled the American roost for the next twelve years, despite consistently failing to live up to its various promises.

Today, other misguided policy entrepreneurs prevail. Some understand even less about the economy than supply-siders. Is there a memetic version of Gresham's Law at work, in which bad ideas tend to drive out good ones? Whether they are good or bad, simple memes propagate more effectively than complicated ones. They can be copied faithfully by politicians and populations alike. One attractively packaged meme can become omnipotent, dominating any local region of political meme-space.

\section{Concluding Remarks}

Our four vignettes have several features in common. First, each shows that memes can exploit our limited capacity to deal collectively with complex problems. They undermine our efforts to grapple with the complexity. Simple memes propagate better for the simple mechanical reason that something simple can be copied with greater fidelity than something complicated. And our own complexity-based work suggests that there is room for only one powerful meme in any local region of meme-space - and such memes will usually be simple.

Thus Universal Darwinism presents a special challenge to public policy, since policies are built from ideas in action. We need to imagine a more complex and organic process where humans and their cultures have limited agency. We need to understand how policy is constructed by and for often short-lived, relatively simple memes, each 
Roughly spliced draft only

In: C Karlsson, Å E Andersson, P C Cheshire and R R Stough (eds) (2009) New directions in regional economic development. Heidelberg, Springer. pp 97-105

with their own selfish interests, within a complex framework of culture built by relatively longer-lived genes and memes, again each with their own selfish interests.

We need, in short, to bring memes and complex systems into the arena of public policy - whether regional, national or international. Then, perhaps, our limited abilities to address complex problems collectively might advance.

\section{References}

1. D. C. Dennett, in Darwinizing culture: The status of memetics as a science. R. Aunger, ed. (Oxford University Press, Oxford, 2000) pp. vii - ix.

2. D. Batten, S. Blackmore, F. Boschetti, R. Bradbury, S. Callahan, I. Enting, J. Finnigan, A-M. Grisogono, S. Hatfield Dodds, D. Newth, A. Rixon, R. Seymour, A. Wardell-Johnson and R. Williams, mimeo to be submitted to Science.

3. R. Dawkins, The selfish gene (Oxford University Press, Oxford, 1976; Revised edition with additional material, 1989).

4. P. W. Anderson, K. J. Arrow, D. Pines, eds., The economy as an evolving complex system (Addison Wesley, New York, 1988).

5. J. M. Epstein, R. L. Axtell, Growing artificial societies: Social science from the bottom up (Brookings Institution Press, Washington, 1996).

6. J. H. Holland, Emergence: From chaos to order (Oxford University Press, Oxford, 1998).

7. R. Dawkins, The extended phenotype: the gene as the unit of selection (W. H. Freeman, Oxford, 1982).

8. D. C. Dennett, Darwin's dangerous idea: evolution and the meanings of life (Simon \& Schuster, New York, 1995).

9. A. Aguzzi, C. Haass, Science 302, 814-818 (31 October 2003, 2003).

10. C. G. Langton, Artificial life: an overview (MIT Press, Cambridge, MA, 1995).

11. S. Blackmore, The meme machine (Oxford University Press, Oxford, 1999).

12. M. Eigen, Steps towards life (Oxford University Press, Oxford, 1992).

13. D. L. Hull, in Darwinizing culture: The status of memetics as a science R. Aunger, Ed. (Oxford University Press, Oxford, 2000) pp. 43-67. 
Roughly spliced draft only

In: C Karlsson, Å E Andersson, P C Cheshire and R R Stough (eds) (2009) New directions in regional economic development. Heidelberg, Springer. pp 97-105

14. S. Blackmore, Consciousness: An introduction (Hodder and Stoughton, London, 2003).

15. D. C. Dennett, Freedom evolves (Viking Books, New York, 2003).

16. R. Axelrod, The evolution of cooperation (Basic Books, New York, 1984).

17. P. Davies, Foreign Policy 144, 36 - 38 (September/October 2004, 2004).

18. A. M. Rivlin, Foreign Policy 144, $45-46$ (September/October 2004, 2004).

19. P. Krugman, Peddling prosperity: Economic sense and nonsense in the age of diminished expectations (W.W. Norton, New York, 1994). 